\title{
Determining relevant petiole anatomy characters to delimit Eupolypods I families
}

\author{
JEANETTE MARA P. TAN", INOCENCIO E. BUOT, JR. \\ Institute of Biological Sciences, College of Arts and Sciences, University of the Philippines Los Baños, College, Laguna 4031, Philippines. \\ vemail: jptan7@up.edu.ph
}

Manuscript received: 2 April 2020. Revision accepted: 23 May 2020.

\begin{abstract}
Tan JMP, Buot Jr. IE. 2020. Determining relevant petiole anatomy characters to delimit Eupolypods I families. Biodiversitas 21: 2721-2726. The delineation of the families under eupolypods I has been quite challenging. With that, characters that are stable and taxonomically significant are necessary. The study attempted to use petiole anatomy characters to study the taxonomy of the e upolypods I families. Fresh eupolypods I representatives were collected from the field and were fixed with formalin-acetic acid alcohol (FAA). The petioles were cut and processed into permanent mounts using alcohol dehydration series and following standard microtechnique protocols. The petiole anatomy characters of the 21 representative species of eupolypods I were first studied of their stability and subjected to multiple correspondence analysis (MCA) to determine the most taxonomically relevant character. The MCA biplot showed that four petiole anatomy characters were useful to describe and delineate families of eupolypods I. These petiole anatomy characters included, xylem shape, vascular bundle shape, and number of vascular bundles.
\end{abstract}

Keywords: Eupolypods I, multiple correspondence analysis, petiole anatomy, stable characters

\section{INTRODUCTION}

Up to the present, the taxonomic placement of species under eupolypods I families is unstable. Due to lumping and shifting of families, delineating families is becoming challenging, particularly concerning characters unique to the clade or family (Christenhusz and Chase 2014). Fortunately, anatomical structures provide strong evidence in terms of delineating larger groups such as families and aid in distinguishing genera of uncertain taxonomic status. It is also significant in identifying individual species particularly to specimens without floral parts. Numerous studies showed the importance of petiole anatomy to seed plants. One such study was that of Samiyarsih et al. (2019) on Catharanthus roseus variability. Another one was the work of Pitoyo et al. (2018) in their study of Colocasia esculenta from southeastern part of Central Java, Indonesia.

Petiole anatomy was also found to be useful in systematic studies of ferns. In fact, each species was found to exhibit unique petiole anatomical characteristics that can be used to delineate one species from the other (Resmi et al. 2016). Sofiyanti et al. (2019) were able to characterize the four common ferns of Pekanbaru, Riau Province, Indonesia using petiole anatomy. The study clearly illustrated that the species share the same amphicribral concentric vascular bundles but differ in size within species. Petiole anatomy was very helpful also in the study of Tan et al. (2020) to describe, delineate, and classify species of eupolypods I.

Numerous authors have considered the structure of the vascular bundles as basis for differentiating various taxonomic groups. Martínez and Vilte (2012) were able to generate a classification of the twelve species of Pteris using shape and number of vascular bundles. Diverse morphological states of the vascular bundles include the shape of xylem, shape, and number of vascular bundles. Another study (Hernandez-Hernandez et al. 2012) showed the different shapes of vascular bundles of the 89 fern species and that it correlated with the presence of circumendodermal band.

The circumendodermal band is composed of distinct cells surrounding the vascular bundles and endodermis which are distinct with or without stains (HernandezHernandez 2009). This band originated from parenchyma cells which protect the phloem (Russow 1872). The term 'circumendodermal band' was attributed to this group of cells on account of its proximity to the endodermis. Considering the position of the circumendodermal band, there could be two possible functions, namely (HernandezHernandez et al. 2012); (i) protection against microorganisms and other pathogens; and (ii) protection against stresses.

Hence, petiole anatomy characters are indeed stable and can be utilized in taxonomic studies. According to Metcalfe and Chalk (1950), it is of great importance to rely on anatomical structures that are taxonomically well established. Actually, there are many petiole anatomy characters but we need to be very strategic so that we will utilize only the most stable ones. The objectives of this study therefore, were: (i) to determine the key taxonomic characters of the eupolypods I petiole anatomy and (ii) to identify those stable characters that delimit families of eupolypods I using multiple correspondence analysis. 


\section{MATERIALS AND METHODS}

\section{Selection and preparation of the fresh Eupolypods representative specimens}

A total of 21 representatives of eupolypods I were studied. Twenty specimens were fresh samples from the field (Mt. Makiling Forest Reserve, Los Baños, Laguna; Quezon-Laguna UP Land Grant; and Mt. Mantalingahan Protected Landscape, Palawan, Philippines). These were as follows: Davallia hymenophylloides, Davallia solida, Davallia repens (Davalliaceae); Bolbitis heteroclita, Polystichum horizontale, Arachniodes amabilis (Dryopteridaceae); Hypodematium crenatum (Hypodematiaceae); Oleandra maquilingensis (Oleandraceae), Lomariopsis lineata, Lomariopsis kingii, Cyclopeltis crenata (Lomariopsidaceae), Nephrolepis cordifolia, Nephrolepis biserrata, Nephrolepis falcata (Nephrolepidaceae); Microsorum heterocarpum, Microsorum punctatum, Phymatosorus scolopendria (Polypodiaceae); Tectaria angulata, Tectaria dissecta, Tectaria hilocarpa (Tectariaceae). One was not spotted though during fieldwork (Didymochlaena truncatula (Didymochlaenaceae), hence, we used the description of Zhang and Zhang (2015) for the purpose of this study.

The petioles of each specimen were cut into three parts: basal region (next to the rhizome), middle region (half of the petiole), and distal region (next to the blade) and were fixed and preserved in formalin-acetic acid alcohol (FAA) (Johansen 1940). Free-hand sectioning technique was used, and the specimens underwent the alcohol dehydration series and permanently mounted using Canada Balsam. Permanent slides were deposited in the Plant Biology Division Herbarium, Institute of Biological Sciences, University of the Philippines Los Baños, Laguna, Philippines. Cross-section of the petioles were observed using Olympus light compound microscope. Images were documented, and scales of each section were obtained through ImageJ software, generating scales through pixels of the photo.

\section{Determining delimiting taxonomic characters of Eupolypods I}

The data obtained from petiole anatomy were analyzed. Stable characters were determined by examining each species collected from different environments, particularly, substrates, gradients, and altitude. Those characters that remained constant were chosen and further analyzed using Multiple Correspondence Analysis, FactoMineR package (MCA) (Sebastien et al. 2008). MCA is equivalent to Principal Component Analysis for nominal data and can be used for qualitative variables (Le Roux and Rouanet 2010).

\section{RESULTS AND DISCUSSION}

\section{Stable and distinct petiole anatomy characters of the nine families of Eupolypods I}

Eupolypods I families exhibited unique petiole anatomy characters such as diverse stelar shape, xylem shape, vascular bundle shape, vascular bundle number, circumendodermal band, and adaxial grooves (Figure 1). Each family showed similarities and differences in terms of the presence circumendodermal band, number of vascular bundles, and xylem strand shape. For instance, Davalliaceae species showed the presence of circumendodermal band, U-shaped vascular bundles, and arc-shaped xylem strand shape (except $D$. hymenophylloides with V-shaped xylem) (Figures 1.A-C). Also, Dryopteridaceae species showed similar arc-shaped xylem but out of the three species examined, Bolbitis heteroclita and Polystichum horizontale showed the presence of circumendodermal band except for Arachniodes amabilis which does not have circumendodermal band (Figures 1.D-F). Moreover, the species under Hypodematiaceae (Figure 1.G) and Oleandraceae (Figure 1.H) showed similar arc-shaped xylem strand and has circumendodermal band. However, one distinct character of Hypodematiaceae is the presence of only two vascular bundles unlike Oleandraceae having three vascular bundles. Furthermore, the other four families have the presence of circumendodermal band in various thicknesses but have distinct characteristics. Lomariopsidaceae species (Figures 1.I-K) shared the same S-shaped xylem strand while species of Tectariaceae (Figure 1R-T) have hook-shaped xylem strand. On the other hand, the species under Nephrolepidaceae (Figures 1.L-N) and Polypodiaceae (Figures 1.O-Q) have similar Cshaped xylem strands.

These characters were screened based on stability across varying environments. It was observed that xylem shape, vascular bundle shape, and number of vascular bundles of species from different habitat, substrate, and elevation, remained constant across varying environmental conditions. Table 1 presented petiole characters of the same species collected from different elevation, collection sites, and habits so as to clearly illustrate the stable and unstable petiole anatomy characters. Despite differences in microenvironmental states, species showed similar petiole anatomy characters such as xylem shape, vascular bundle shape, and number of vascular bundles (Table 1).

This indicated that these character states are more or less stable. Transverse section of Microsorum heterocarpum collected from $352 \mathrm{~m}$ asl and $1230 \mathrm{~m}$ asl, showed similar C-shaped xylem, U-shaped vascular bundle, and 3 to 4 vascular bundles (Table 1). If this petiole anatomy character were unstable, the one collected from $352 \mathrm{~m}$ asl should have possessed a different petiole anatomy character from the one collected from $1230 \mathrm{~m}$ asl. Further, the transverse sections of Lomariopsis lineata which were collected from Mt. Makiling (lithophyte) and Mt. Mantalingahan (epiphyte), showed similar S-shaped xylem, U-shaped vascular bundle, and 2-5 vascular bundles (Table 1). These remarkable observations illustrated that vascular bundles are constant and stable characters (Table 1 ), and hence, can be useful taxonomic and systematic characters.

After analysis of Table 1, the following petiole anatomy characters were found constant even if collected from varying environmental conditions: stellar type, xylem strand shape, shape of vascular bundles, and number of 
vascular bundles. Based on the studies of Ogura (1972), Lin and De Vol (1977), Hernandez-Hernandez et al. (2012), and Noraini et al. (2012), these characters are taxonomically and systematically significant. Also, the architecture of vascular bundles was conserved for a long time starting from the Upper Jurassic to the Cretaceous period (Hacke and Sperry 2001), making it a very stable character.

\section{Delimiting petiole anatomy characters of the Eupolypods I families}

The four petiole anatomy characters, namely, type of stele, xylem shape, vascular bundle shape, and number of vascular bundles were subjected to MCA, in order to determine which were the delineating characters. Based on the MCA biplot, the distinct petiole anatomy characters delimiting eupolypods I families were grouped together. Meanwhile, those characters such as dictyostele, V-shaped vascular bundles, and U-shaped vascular bundles that were common to two or more families were separated from other families (Figure 2). Those species under one family were also grouped together. This implied that characters that were clumped nearest to the families were those distinct and unique characters that can be used to identify and distinguish the specific families (Figure 2).

It is very clear that three petiole anatomy characters, including xylem shape, vascular bundle shape, and number of vascular bundles were found to delimit each family. The following characters were the petiole anatomy characters found to be useful in distinguishing families of eupolypods I based on the Multiple Analysis Biplot (MCA): Davalliaceae-arc-shaped xylem and one to five vascular bundles; Didymochlaenaceae-arc-shaped xylem, semi- circle, and three vascular bundles; Dryopteridaceae-arcshaped xylem, U-shaped and three vascular bundles; Hypodematiaceae-two vascular bundles; Lomariopsidaceae-S-shaped xylem, two to five vascular bundles; Nephrolepidaceae-C-shaped xylem and three to five vascular bundles; Oleandraceae-arc-shaped xylem, Vshaped and two to three vascular bundles; PolypodiaceaeC-shaped xylem, U-shaped and three to four vascular bundles; and Tectariaceae-hook-shaped xylem and three to seventeen vascular bundles.

The number and the shape of the vascular bundle and xylem strands distinguished the family. The three distinct characters observed for Polypodiaceae (U-shaped vascular bundles with C-shaped xylem strand, and 3-4 vascular bundles) corresponded to the findings of Hennipman (1990) (Figure 3.E). This study also illustrated that Nephrolepidaceae (Figure 3.G) has C-shaped xylem and 35 vascular bundle characters while Lomariopsidaceae (Figure 3.H) has S-shaped xylem strand and 2-5 vascular bundles in U-shaped. Until now, there is an ongoing debate about the relationship of Nephrolepidaceae and Lomariopsidaceae. PPG I (2016) considered both families as sister families, however, Liu et al. (2013), Kuo et al. (2011), and Testo and Sundue (2016) disagree. Through molecular data, they considered Nephrolepidaceae as sister to a larger clade including Polypodiaceae, Tectariaceae, Davalliaceae, and Oleandraceae congruent to the results of the study of Kramer (1990). Results of this study using petiole anatomy characters or evidence proved that Nephrolepidaceae and Lomariopsidaceae are not sister families supporting Liu et al. (2013), Kuo et al. (2011), and Testo and Sundue (2016) but contradicting the claims of PPG I (2016).
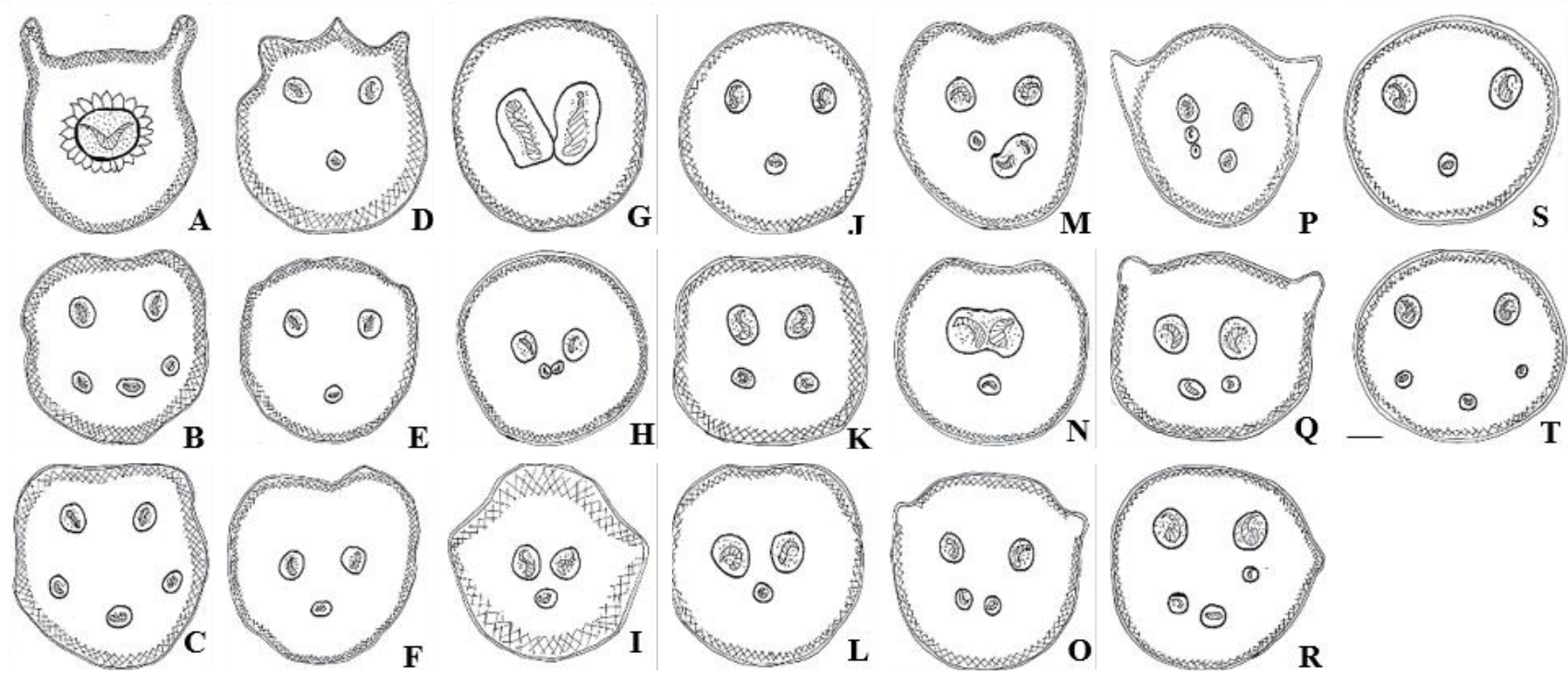

Figure 1. Hand illustrations of the cross-sections of eupolypods I families petiole cross-sections showing the vascular bundle arrangement of the middle petiole. (A) Davallia hymenophylloides, (B) Davallia solida, (C) Davallia repens, (D) Bolbitis heteroclita, (E) Polystichum horizontale, (F) Arachniodes amabilis, (G) Hypodematium crenatum, (H) Oleandra maquilingensis, (I) Lomariopsis lineata, (J) Lomariopsis kingii, (K) Cyclopeltis crenata, (L) Nephrolepis cordifolia, (M) Nephrolepis biserrata, (N) Nephrolepis falcata, (O) Microsorum heterocarpum, (P) Microsorum punctatum, (Q), Phymatosorus scolopendria (R) Tectaria angulata, (S) Tectaria dissecta, and (T) Tectaria hilocarpa . grid = sclerenchyma, thick line $=$ endodermis + pericycle, dotted $=$ phloem, parallel lines $=\mathrm{xylem}$. Bars. A-I $500 \mu \mathrm{m}(40 \mathrm{x})$. 


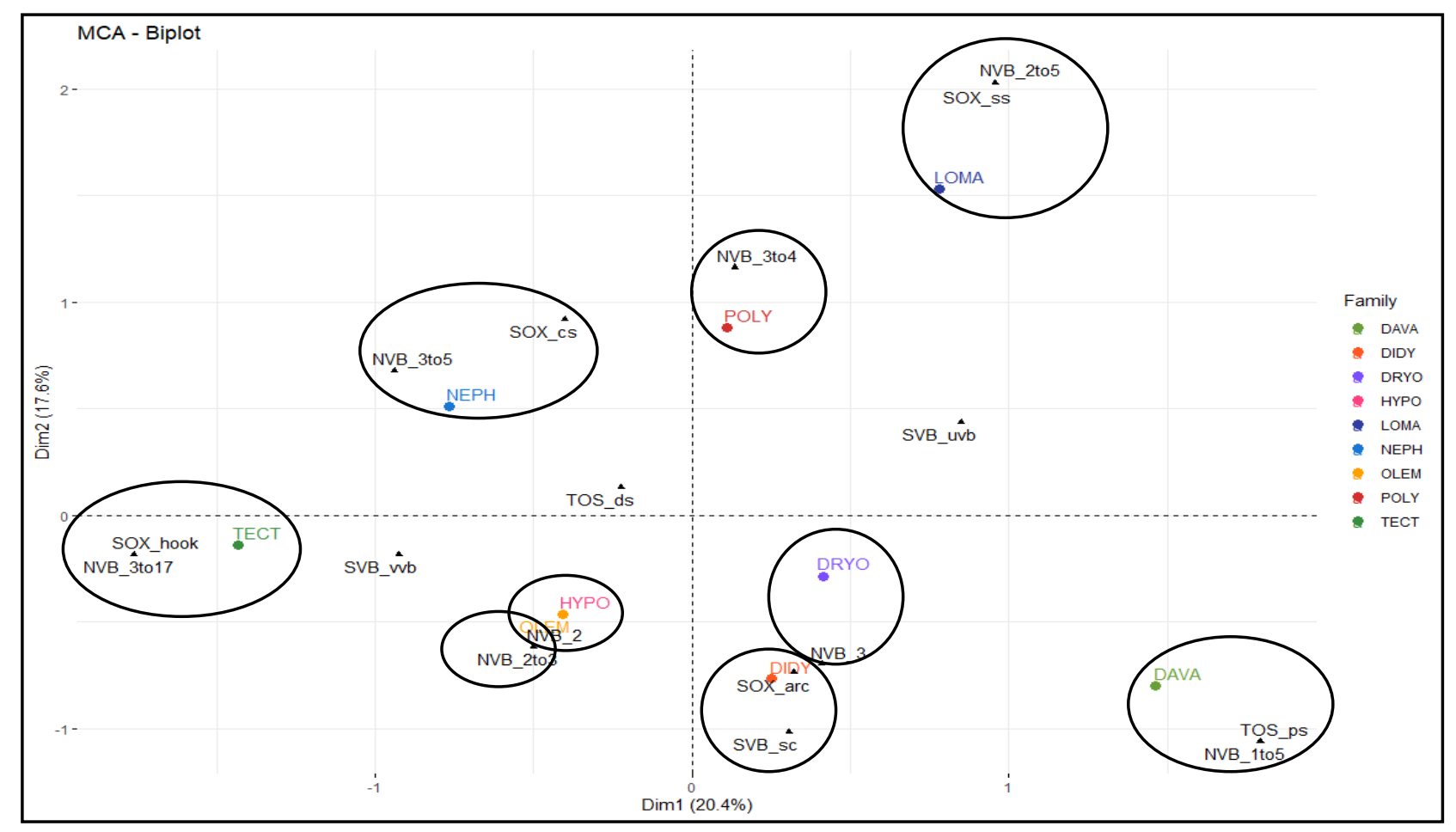

Figure 2. Multiple correspondence analysis biplots of the nine families of eupolypods I using four petiole anatomy characters. (DAVADavalliaceae, DIDY-Didymochlaenaceae, DRYO-Dryopteridaceae, HYPO-Hypodematiaceae, LOMA-Lomariopsidaceae, NEPHNephrolepidaceae, OLEA-Oleandraceae, POLY-Polypodiaceae, TECT-Tectariaceae)
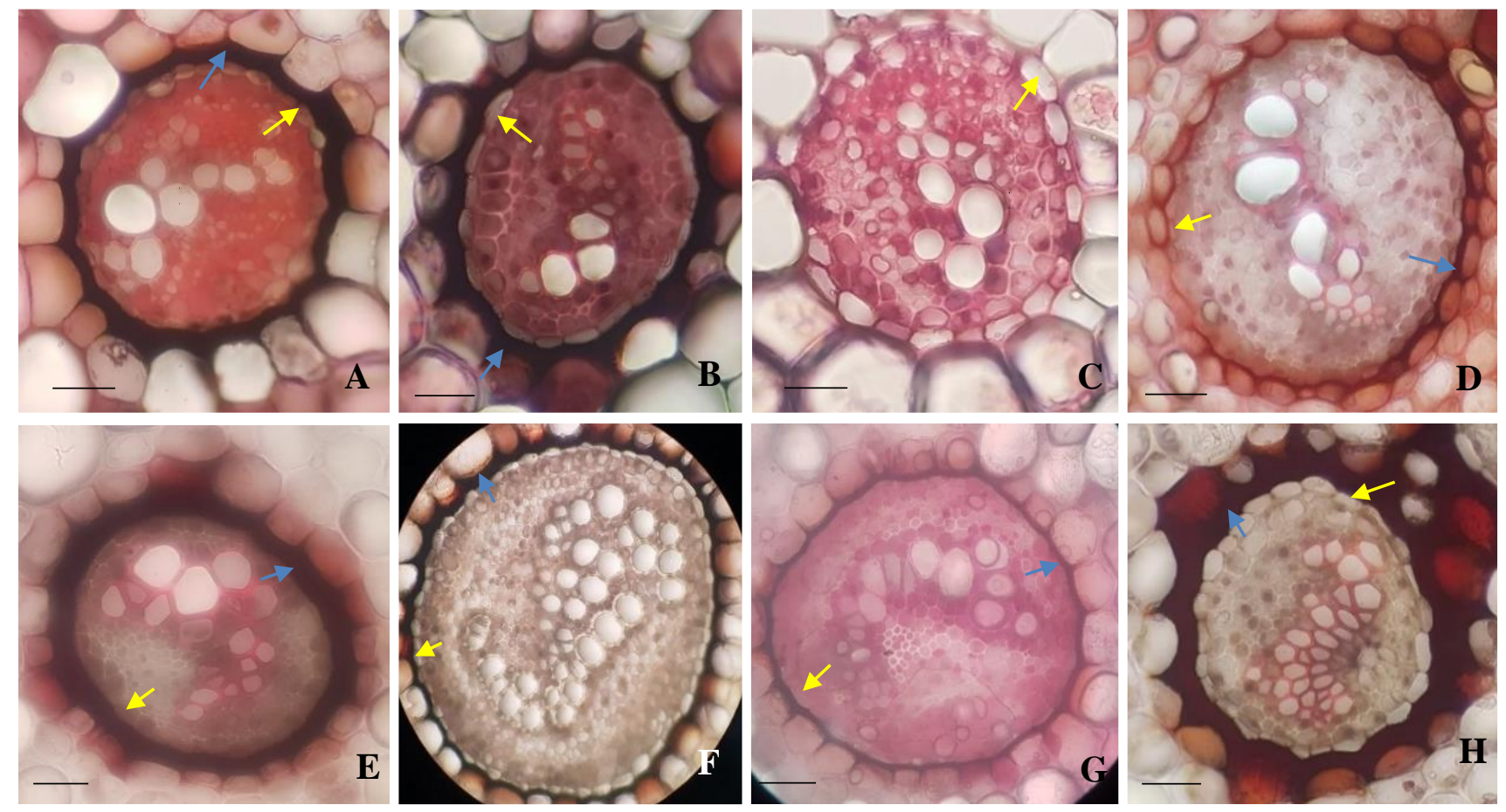

Figure 3. Transverse sections of eupolypods I petiole specimens obtained from the middle region of the petiole (A) Davallia solida (Davalliaceae), (B) Bolbitis heteroclita (Dryopteridaceae), (C) Hypodematium crenatum (Hypodematiaceae), (D) Oleandra maquilingensis (Oleandraceae), (E) Microsorum punctatum (Polypodiaceae), (F) Tectaria angulata (Tectariaceae), (G) Nephrolepis cordifolia (Nephrolepidaceae), and $(\mathrm{H})$ Cyclopeltis crenata (Lomariopsidaceae) (x-xylem, yellow arrow-endodermis, blue arrowcircumendodermal band). Bars. a-c $100 \mu \mathrm{m}(100 \mathrm{x})$. 
Table 1. Stability of some petiole anatomy characters of eupolypods I of different habits and in varying collection sites and elevation in the Philippines

\begin{tabular}{|c|c|c|c|c|c|c|}
\hline \multirow[b]{2}{*}{ Species } & \multirow[b]{2}{*}{ Habit } & \multirow[b]{2}{*}{$\begin{array}{l}\text { Collection } \\
\text { site }\end{array}$} & \multicolumn{4}{|c|}{ Petiole anatomy characters } \\
\hline & & & $\begin{array}{l}\text { Elevation } \\
\text { (m asl) }\end{array}$ & $\begin{array}{l}\text { Xylem } \\
\text { shape }\end{array}$ & $\begin{array}{l}\text { Vascular } \\
\text { bundle } \\
\text { shape }\end{array}$ & $\begin{array}{l}\text { Number } \\
\text { of } \\
\text { vascular } \\
\text { bundles }\end{array}$ \\
\hline \multicolumn{7}{|c|}{ Davallia hymenophylloides } \\
\hline J.Tan 6938 (PBDH) & Epiphyte on trunk, shaded & Mt. Makiling & 1103 & V-shaped & U-shaped & 1 to 5 \\
\hline J.Tan 6939 (PBDH) & Epiphyte on trunk, shaded & Mt. Makiling & 1020 & V-shaped & U-shaped & 1 to 5 \\
\hline \multicolumn{7}{|l|}{ Bolbitis heteroclita } \\
\hline J.Tan 6949 (PBDH) & Terrestrial, open canopy & Mt. Makiling & 630 & Arc-shaped & U-shaped & 3 \\
\hline J.Tan 6971 (PBDH) & Lithophytic, shaded & Quezon-Laguna land grant & 446 & Arc-shaped & U-shaped & 3 \\
\hline \multicolumn{7}{|l|}{ Hypodematium crenatum } \\
\hline J.Tan 6978 (PBDH) & Lithophytic, partially shaded & Mt. Makiling & 287 & Arc-shaped & V-shaped & 2 \\
\hline J.Tan 6979 (PBDH) & Lithophytic, open canopy & Mt. Makiling & 450 & Arc-shaped & V-shaped & 2 \\
\hline \multicolumn{7}{|l|}{ Nephrolepis biserrata } \\
\hline J.Tan 6946 (PBDH) & Terrestrial & Mt. Makiling & 435 & C-shaped & V-shaped & 3 to 5 \\
\hline J.Tan 6946b (PBDH) & Epiphyte & Mt. Mantalingahan & 419 & C-shaped & V-shaped & 3 to 5 \\
\hline \multicolumn{7}{|l|}{ Microsorum heterocarpum } \\
\hline J.Tan $6985(\mathrm{PBDH})$ & Lithophytic, on creeks & Mt. Makiling & 352 & C-shaped & U-shaped & 3 to 4 \\
\hline J.Tan 6985b (PBDH) & Epiphyte & Mt. Makiling & 1230 & C-shaped & U-shaped & 3 to 4 \\
\hline \multicolumn{7}{|l|}{ Lomariopsis lineata } \\
\hline J.Tan $6986(\mathrm{PBDH})$ & Lithophytic & Mt. Makiling & 710 & S-shaped & U-shaped & 2 to 5 \\
\hline J.Tan 6987 (PBDH) & Epiphytic & Mt. Mantalingahan & 653 & S-shaped & U-shaped & 2 to 5 \\
\hline \multicolumn{7}{|l|}{ Tectaria angulata } \\
\hline J.Tan 6994 (PBDH) & Terrestrial, shaded & Mt. Makiling & 159 & Hook-shaped & V-shaped & 3 to 17 \\
\hline J.Tan 6995 (PBDH) & Terrestrial, open canopy & Mt. Mantalingahan & 190 & Hook-shaped & V-shaped & 3 to 17 \\
\hline \multicolumn{7}{|l|}{ Oleandra maquilingensis } \\
\hline J.Tan $6976(\mathrm{PBDH})$ & Epiphyte & Mt. Makiling & 1045 & Arc-shaped & V-shaped & 2 to 3 \\
\hline J.Tan 6977 (PBDH) & Epiphyte & Mt. Makiling & 1020 & Arc-shaped & V-shaped & 2 to 3 \\
\hline
\end{tabular}

Davalliaceae can be identified using the following characters: protostele and dictyostele, arc-shaped xylem, and 1-5 vascular bundles (Figure 3.A). This exactly agrees with the result of Noraini et al. (2012), Kramer (1990), and Kato and Mitsuta (1980). Meanwhile, Hypodematiaceae sets apart from the rest of the families under eupolypods I by having only two vascular bundles (Figure 3.C) which eventually fused as it reached the distal region of the petiole supporting the findings of Khare and Shankar (1987). This character as seen in Figure 3 is nearest and closely related to Hypodematiaceae making it a unique and distinct character. Currently, the taxonomic position of Hypodematium is still uncertain. It was moved from one family to another until PPG I moved it to its own family Hypodematiaceae (Tan et al. 2020).

Based on petiole anatomy characters, both Didymochlaenaceae and Dryopteridaceae shared the same arc-shaped xylem, but Didymochlaenaceae differs by having three semi-circle shaped vascular bundles. On the other hand, Dryopteridaceae showed three U-shaped vascular bundles that delimit the family Dryopteridaceeae from other families under eupolypods I similar to the findings of Kramer (1990) (Figure 3.B).

It can be observed that Didymochlaenaceae is related to Dryopteridaceae. Previously, molecular data considered Didymochlaena as a member of Dryopteridaceae (Ching 1965; Tryon and Tryon 1982; Kramer et al. 1990). However, recent molecular studies confirmed that it merits its own family Didymochlaenaceae and a member of eupolypods I (Zhang and Zhang 2015). The petiole anatomy results showed that Didymochlaenaceae, whose taxonomic placement has always been a subject of controversy, merits its own family and not part of Dryopteridaceae which conforms to the findings of PPG I.

Finally, the petiole anatomy of family Oleandraceae with its representative genus, Oleandra is illustrated in Figure 3.D. Results showed that Oleandraceae can be uniquely characterized as having 2-3 U shaped vascular bundles which conform with the study of Kramer (1990). The results indicated support to the current circumscription of Oleandra in its own family Oleandraceae.

The distinctiveness and species delineation of Oleandra and Oleandraceae are still uncertain and difficult (Smith et al. 2006). In fact, this family has been previously linked to other families such as Davalliaceae, Nephrolepidaceae, and Dryopteridaceae (Tan et al. 2020). The circumscription of this family has been challenging as many of the species are similar in appearance (Kramer 1990).

In conclusion, the multiple correspondence analysis generated three stable and significant petiole anatomy characters, delineating eupolypods I families, namely; xylem shape, shape of the vascular bundle, and number of vascular bundles. This finding implied that these characters are most relevant in the classification and identification of eupolypods 1 families and species. Similar anatomical 
features may have high potentials in characterizing and delineating other groups of ferns too.

\section{ACKNOWLEDGEMENTS}

The authors would like to express their appreciation to the Department of Science and Technology-Accelerated Science and Technology Human Resource Development Program, (DOST-ASTHRDP) for financial support in the conduct of the study. The University of the Philippines Los Baños allowed the conduct of fieldworks in Mt. Makiling and Quezon-Laguna UP Land Grant. Some species were collected from Mt. Mantalingahan, Palawan, Philippines under the comprehensive biodiversity project of Associate Prof. Pastor Malabrigo, with a Gratuitous Permit No. 201925. Also, the Plant Systematics Laboratory of the Institute of Biological Sciences, University of the Philippines Los Baños, provided space for study and discussion.

\section{REFERENCES}

Ching RC. 1965. Dryopteridaceae: A new fern family. Acta Phytotax Sin 10: $1-5$.

Christenhusz M, Chase M. 2014. Trends and concepts in fern classifcation. Ann Bot 113 (4): 571-594.

Hacke UG, Sperry JS. 2001. Functional and ecological xylem anatomy. Perspect Plant Ecol Evol Syst 4 (2): 97-115.

Hennipman et.al. 1990. Polypodiaceae. In: Kramer et al. (ed) Pteridophytes and Gymnosperms. Springer, Berlin.

Hernandez-Hernandez VT, Terrazas K, Mehltreter, Angeles G. 2012 Studies of petiolar anatomy in ferns: structural diversity and systematic significance of the circumendodermal band. Bot J Linn Soc 169 (4): 596-610.

Hernandez-Hernandez V, Terrazas T, Stevenson DW. 2009. Ontogeny of Ctenitis melanosticta (Kunze) Copel. and Diplazium expansum Willd. (Dryopteridaceae) fronds with emphasis on the circumendodermal sheath. Feddes Repertorium 120 (7-8): 426-442.

Johansen DA. 1940. Plant Microtechnique. McGraw Hill, NewYork.

Kato M, Mitsuta S. 1980. Stelar organization in davallioid ferns. Phytomorphology 29: 362-369.

Khare PK, Shankar R. 1987. Variations in petiolar structure of Hypodematium crenatum. Am Fern J 77 (4): 131-136.

Kramer KU 1990. Pteridophytes and Gymnosperms. The Families and Genera of Vascular Plants. Vol 1. Springer, Berlin.

Kramer KU, Holttum RE, Moran RC, Smith AR. 1990. Dryopteridaceae. In: Kramer KU, Green PS. (eds) The families and genera of vascular plants. Vol. 1. Pteridophytes and Gymnosperms (ser. ed., Kubitzki K.). Springer, Berlin.

Kuo LY, Li FW, Chiong WL, Wang CN. 2011. First insights into fern matK phylogeny. Mol Phylogenet Evol 59: 556-566.

Le Roux B, Rouanet H. 2010. Multiple Correspondence Analysis (Vol. 163). Sage, New York.

Lin BL, Devol CE. 1977. The use of stipe characters in fern taxonomy I. Taiwania 22 (1): 91-99.

Liu HM, Jiang RH, Guo J, Hovenkamp P, Perrie LR, Shepherd L, Hennequin S, Schneider H. 2013. Towards a phylogenetic classification of the climbing fern genus Arthropteris. Taxon 62: 688700 .

Martínez OG, Vilte I. 2012. The structure of petioles in Pteris (Pteridaceae). Am Fern J 102 (1): 1-11.

Metcalfe CR, Chalk L. 1950. Anatomy of The Dicotyledons. Leaves, Stem, and Wood in Relation to Taxonomy with Notes on Economic Uses. Vol. 1. Oxford University Press, UK.

Noraini T, Ruzi AR, Nadiah N, Nisa RN, Maideen H, Solihani SN. 2012. Stipe anatomical characteristics in some Davallia (Davalliaceae) species in Malaysia. Sains Malaysiana 41 (1): 53-62.

Ogura Y. 1972. Comparative Anatomy of Vegetative Organs of the Pteridophytes. Encyclopedia of Plant Anatomy. Schweizerbart Stuttgart.

Pitoyo A, Prameta AA, Marsusi, Suratman, Suranto. 2018. Morphological, anatomical and isozyme variability among taro (Colocasia esculenta) accessions from southeastern part of Central Java, Indonesia. Biodiversitas 19: 1811-1819

Resmi S, Thomas VP, Sreenivas VK. 2016. Stipe anatomical studies on selected pteridophytes of South India. Acta Bot Hung 58 (1-2): 167176.

Russow E. 1872. Comparative studies on the histology (historiography and histogeny) of the vegetative and spore-forming organs and the development of the spores of the vascular cryptogams: with consideration of the histology of the phanerogams, starting from the consideration of the marsiliaceen. Commissionnaires de l'Académie Impériale des sciences, France.

Samiyarsih S, Naipospos N, Palupi D. 2019. Variability of Catharanthus roseus based on morphological and anatomical characters, and chlorophyll contents. Biodiversitas 20: 2986-299.

Sebastien Le, Josse J, Husson F. 2008. FactoMineR: An R package for multivariate analysis. J Statistical Software 25 (1): 1-18.

Smith AR, Pryer KM, Schuettpelz E, Korall P, Schneider H, Wolf PG. 2006. A classification for extant ferns. Taxon 55: 705-731.

Sofiyanti N, Iriani D, Fitmawati, Marpaung AA. 2019. Morphology, palynology, and stipe anatomy of four common ferns from Pekanbaru, Riau Province, Indonesia. Biodiversitas 20: 327-336.

Tan JMP, Banaticla-Hilario MC, Malabrigo P, delos Angeles MD, Buot IE. 2020. Anatomical examination of the petiole of eupolypods I (Polypodiales). Biodiversitas 21: 1767-1777.

Testo W, Sundue M. 2016. A 4000-species dataset provides new insight into the evolution of ferns. Mol Phylogenet Evol 105: 200-211.

Tryon RM, Tryon AF. 1982. Ferns and allied plants, with special reference to tropical America. Springer, Berlin.

Zhang LB, Zhang L. 2015. Didymochlaenaceae: A new fern family of eupolypods I (Polypodiales). Taxon 64: 27-38. 